\title{
Genetic manipulation to be patented?
}

A patent application governing commercial uses of recombinant DNA techniques has been filed in the United States. Colin Norman reports.

WHILE the scientific community has been loudly debating the potential hazards and benefits associated with a new technique for manipulating genes in living organisms, Stanford University and the University of California have been quietly trying to patent the technique in the United States. Rumours about the patent application, which apparently has been pending for at least 18 months, surfaced at a scientific symposium held at the Massachusetts Institute of Technology earlier this month; they were confirmed by university officials last week.

Though the people concerned with the patent application are reluctant to discuss it in detail while the matter is pending, the patent is understood to be worded broadly enough to cover commercial uses of any method of transplanting genes from one organism into another. The patent, if awarded, would not affect research uses of the technique, and it would apply only in the United States.

The basis for the application is research published in 1973 and 1974 by groups led by Stanley Cohen at Stanford and Herbert Boyer at the University of California, San Francisco. Their efforts led to the first demonstration that genes can be snipped from the DNA of virtually any organism and spliced into a bacterial plasmid (a ring of DNA which reproduces inside a bacterium independent of the bacterium's chromosomes). The key part of their research showed that the modified plasmid could be reinserted into a bacterium so that the transplanted, 'foreign' genes are copied each time the bacterium reproduces. It is understood that the patent application covers the process for constructing hybrid DNA moleoules capable of self-reproduction, which means that, if awarded, it would also apply to transplanting genes into viruses and bacteriophages.

There has been speculation that the technique might, eventually, lead to such commercial uses as the insertion into bacteria of genes capable of producing pharmaceutical products, such as insulin, so that specially engineered bacteria would be capable of secreting expensive drugs. Another speculative commercial application would be to graft genes capable of fixing nitrogen into crop plants such as wheat, to produce a new variety capable of synthesising its own nitrogen fertilisers from the atmosphere. Such uses of the technique would be covered by the patent application.

Discussion of the patent application arose at a symposium on genetic manipulation held by Miles Laboratories at MIT on June 8-10. Noting that there have been persistent rumours that somebody is trying to patent the technique, a speaker asked whether any participants could shed some light on the matter. Cohen, who was present at the meeting, confirmed that Stanford and the University of California are looking into the possibility of taking out a patent, and he emphasised that neither he nor any of the other researchers involved would benefit financially if it were awarded.

A patent application can be filed in the United States up to a year after the information on which it is based has been made public. The first paper by Cohen and Boyer's groups was published in November, 1973, which indicates that the application should have been filed before November 1974. Asked last week whether that assumption is correct, a Stanford patent officer replied that "it would be reasonable to assume that we were prudent in filing our application". In some countries, such as Great Britain, a patent must be applied for before any public disclosure is made. Britain's National Research and Development Corporation initially looked into the possibility of seeking a patent on genetic manipulation techniques developed by Kenneth and Noreen Murray at Edinburgh University, but dropped the idea because of prior disclosure.

When the matter was raised at the Miles symposium, two concerns were discussed. First, some scientists were worried that the patent, if awarded, might interfere with research. And second, it was suggested that it may force some commercial concerns to seek a less safe, but patent-free, genetic manipulation technique. Neither concern seems to be valid, however, and in fact the patent, if awarded, could have some safety benefits.

As for the research implications, the patent would apply only to commercial use of the technique-it would not cover either academic or industrial research uses. Moreover, asked whether it may hold up beneficial applications of the technique, a Stanford official argued that royalties derived from the patent would be "reasonable" and would not limit its use.

As far as safety implications are concerned, the application seems to cover the key steps in the genetic manipulation process and thus, unless it is drastically narrowed by the US Patent Office, it would be difficult to see how a different patent-free process could be developed. If the patent is awarded, Cohen suggested at the Miles symposium that Stanford and the University of California could insist that commercial users of the process be required to sign an undertaking to abide by safety guidelines laid down by the National Institutes of Health (NIH).

$\mathrm{NIH}$ is due to issue guidelines on June 23 governing genetic manipulation research which it supports. At a meeting earlier this month, NIH Director Donald Frederickson briefed a number of industry officials on the guidelines, and though they met with general support, some drug company representatives expressed reservations about one or two provisions. The NIH guidelines, moreover, would not be binding on industry, since they would apply only to N.IH-sponsored research. The patent may, therefore, provide a means of extending the coverage of the guidelines.

Cohen and Boyer's work was supported by the National Institutes of Health, but the federal government is unlikely to have a stake in the patent. Stanford has a standing agreement with the Department of Health, Education and Welfare (HEW) which gives the university patent rights on inventions produced from research supported by HEW grants, unless the project has been exempted from the agreement. According to an HEW official, the genetic manipulation studies were not exempted. Stanford patent officers have, however, been discussing the application with federal officials, particularly as regards establishing licensing arrangements if the patent is awarded. $\square$ 